\title{
The Influence Of Managerial Ownership, Institutional Ownership, And Dividend Policy On The Financial Performance Of Construction And Building Companies Listed On The Indonesia Stock Exchange 2013-2017
}

\author{
Yeni Sofiana $^{1}$, Agus Sukoco ${ }^{2}$, Joko Suyono ${ }^{3}$ \\ Departement of Management Student, Faculty of Economics and Business, Narotama University \\ JlArif Rahman Hakim 51 Surabaya, Indonesia 601171,2,3 \\ yenisofiana95@gmail.com ${ }^{1}$, agus.sukoco@narotama.ac.id ${ }^{2}$,joko.suyono@narotama.ac.id ${ }^{3}$
}

\begin{abstract}
Purpose: The purpose of this studyisdetermine the influence of managerial ownership, institutional ownership and dividend policy on corporate financial performance with indicators of Return On Assets (ROA).

Design/methodology/approach: The research method used is multiple linear regression analysis.

Findings: Dividend policy has a negative and significant influence on the company's financial performance.Simultaneously managerial ownership, institutional ownership and dividend policy have a significant influence on the company's financial performance.

Research limitations/implications: This study uses secondary data from construction and building companies sub-sector companies listed on the Indonesia Stock Exchange.

Practical implications: The results of this study are managerial ownership has a positive and significant influence on the company's financial performance.

Originality/value:

Paper type: This paper can be categorized as case study paper.
\end{abstract}

Keywords: Managerial ownership, institutional ownership, dividend policy, corporate financial performance.

$\begin{array}{lll}\text { Received } & : & \text { June } 10^{\text {th }} 2019 \\ \text { Revised } & : & \text { July } 17^{\text {th }} 2019 \\ \text { Published } & : & \text { September } 30^{\text {th }} 2019\end{array}$

\section{INTRODUCTION}

In the past four years infrastructure development in Indonesia has become the most interesting discussion, where there has been a significant increase in the amount of infrastructure development. In 2014 the budget for infrastructure development was 155 trillion rupiah while in 2018 it increased 410 trillion rupiah. Based on data from www.cnbc.indonesia.com the operating income of construction companies in Indonesia in the last five years has experienced an average growth of $23 \%$ and net income of $30.6 \%$. The Ministry of State-Owned Enterprises in Indonesia reported that eleven redplate construction companies recorded profits earned in 2017 of 11.24 trillion rupiah and 6.68 trillion rupiah in 2016.

The success of the company in increasing net income can not be separated from good cooperation between the management and the owner of the company in realizing the company's goals. The measure of success of each business can be interpreted as the company's financial performance. In the process of improving financial performance there will be a conflict of interest between the management and the owner of the company. The management is required to be able to increase profits to the maximum extent possible so that the owner of the company also experiences an increase in welfare, so that management often has goals that are different from the company's main objectives.(Yadnyana \& Wati, 2011).

The existence of conflict differences between management and company owners can be influenced by the ownership structure of the company, namely managerial ownership and institutional ownership(Jensen \& Meckling, 1976). The company owner can minimize the risk of the conflict by giving the management the opportunity to be involved in the company's share ownership. With the involvement of share ownership,

The Influence Of Managerial Ownership, Institutional Ownership, And Dividend Policy On The Financial Performance Of Construction And Building Companies Listed On The Indonesia Stock Exchange 2013-2017

Yeni Sofiana $^{1}$, Agus Sukoco ${ }^{2}$, Joko Suyono ${ }^{3}$ 
management will be motivated to improve its performance in managing the company so that it can improve the company's financial performance.Furthermore, institutional ownership also has the role of increasing financial performance because it can be a supervisor of management performance through institutional investors. It is expected that management can provide tangible evidence that the company's financial performance in a stable condition tends to increase so that it can attract investors.Besides managerial and institutional share ownership, financial performance can also be influenced by dividend policy because dividend policy is related to whether the company's cash flow will be paid to shareholders in the form of dividends or reinvested by the company in the form of retained earnings(Weston \& Copeland, 1992).

Based on the phenomena and theories and previous research regarding factors that can affect financial performance, it should be that with the development of infrastructure in Indonesia, the profits obtained by the company are higher and financial performance also looks good, but in reality not all company profits have increased.This is where the function of the influence of shareholders should be seen, therefore, an analysis is needed which can determine the influence of the managerial, institutional and dividend policies on the company's financial performance.Therefore, this research entitled " The Influence of Managerial Ownership, Institutional Ownership and Dividend Policy on Financial Performance in Construction Companies and Buildings Listed on the Indonesia Stock Exchange in 2013 - 2017".

Based on the background described above, the problems that will be examined in this study can be determined, namely:

1. Does managerial ownership partially influence the financial performance of construction and building companies listed on the Indonesia Stock Exchange in 2013-2017?

2. Does institutionalownership partially influence the financial performance of construction and building companies listed on the Indonesia Stock Exchange in 2013-2017 ?

3. Does dividend policy partially influence the financial performance of construction and building companies listed on the Indonesia Stock Exchange in 2013-2017?

4. Do managerial ownership, institutional ownership and dividend policy simultaneously influence the financial performance of construction and building companies listed on the Indonesia Stock Exchange in 2013-2017?

\section{LITERATURE REVIEWS ANDHYPOTHESES}

\section{Managerial Ownership}

Managerial ownership is the proportion of ordinary shares held by management, which can be measured from the percentage of ordinary shares held by management who are actively involved in corporate decision making. According to Melinda \& Sutejo (2019) managerial ownership is the percentage of votes related to shares and options owned by the manager and commissioner of the company. Managerial ownership can be used as a tool for monitoring the manager's performance internally. Managerial ownership is share ownership by company management as measured by the percentage of shares held by management (Sujoko \& Subiantoro, 2007). The formula of managerial ownership is as follows:

$$
\text { Managerial Ownership }=\frac{\text { Managerial Share Amount }}{\text { Total outstanding shares }} \times 100 \%
$$

\section{Institutional Ownership}

Institutional ownership is ownership of shares in the company owned by non-bank financial institutions that manage funds on behalf of other people (Houston \& Brigham, 2009). The examples of nonbank financial institutions are insurance companies, investment companies, mutual fund companies, money market dealers, leasing companies, pension funds companies, consumer finance companies and other nonbank financial institutions.

With this institutional ownership, there will be an assumption that the institutional owner will pay more attention to the management of the company so that it will have a positive influence on the company's financial performance.

Institutional ownership can be measured using the percentage indicator of the number of shares held by institutional parties of the total number of shares of the company (Boediono, 2005). The formula of institusional ownership is as follows:

$$
\text { Institutional Ownership }=\frac{\text { InstitusionalShare Amount }}{\text { Total outstanding shares }} \times 100 \%
$$




\section{Dividend Policy}

Dividend policy is a decision to determine the amount of the share of income to be shared with shareholders and the portion that will be held in the company (Weston \& Copeland, 1996: 215). Dividend policy concerns the issue of the use of profits that are the rights of shareholders, and the profit can be divided as dividends or retained earnings to be reinvested (Husnan \& Pujiastuti, 1998: 381).The ratio of dividend payout ratio (DPR) according to Sartono (2001: 381) is the percentage of profit paid in the form of dividends, or the ratio between profits paid in the form of dividends and total profits available to shareholders. The formula of dividen policy is as follows

$$
\text { Dividend Payout Ratio(DPR)= } \frac{\text { Dividend Per Share }}{\text { Earning Per Share }} 100 \%
$$

\section{Company Financial Performance}

Financial performance is an analysis conducted to see the extent to which a company has implemented it using the rules of financial implementation properly and correctly (Fahmi, 2012).

The description of the company's financial condition in a certain period can be calculated using the Profitability Ratio. The profitability ratio used in this study is the ratio of Return on Assets (ROA), which is a ratio used to show the ability of a company to generate profits by using the total assets of the company (Kasmir, 2016: 201). ROA can be obtained by comparing net income after tax to total assets using the following formula:

$$
\text { Returnon Assets }=\frac{\text { Net Profit }}{\text { Total Assets }}
$$

\section{Hypothesis}

The following is the conceptual framework in this study:

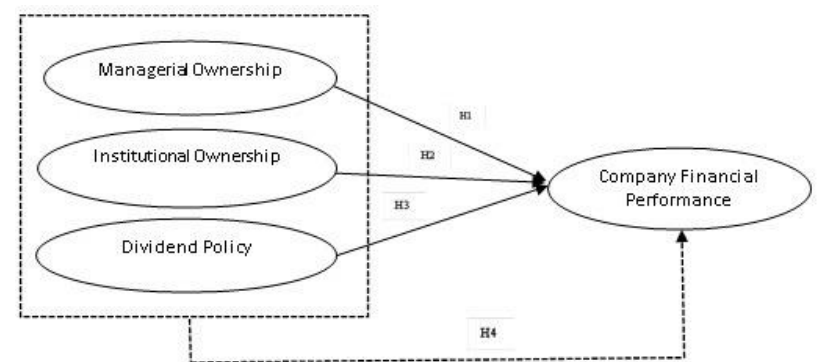

Figure 1. Research Model

As per the formulation of the problem and the conceptual framework expressed above, the hypothesis proposed is:

H1: Managerial ownership has a positive and significant influence on financial performance of construction and building companies listed on the Indonesia Stock Exchange in 2013-2017..

$\mathrm{H} 2$ : Institutional ownership has a positive and significant influence on financial performance of construction and building companies listed on the Indonesia Stock Exchange in 2013-2017.

H3: Dividend policy has a positive and significant influence on financial performance of construction and building companies listed on the Indonesia Stock Exchange in 2013-2017.

H4: Managerial ownership, institutional ownership and dividend policy simultaneously have a positive and significant influence on the financial performance of construction and building companies listed on the Indonesia Stock Exchange in 2013-2017.

\section{METHODS}

The Influence Of Managerial Ownership, Institutional Ownership, And Dividend Policy On The Financial Performance Of Construction And Building Companies Listed On The Indonesia Stock Exchange 2013-2017

Yeni Sofiana $^{1}$, Agus Sukoco ${ }^{2}$, Joko Suyono ${ }^{3}$ 


\section{Types of research}

This type of research is quantitative associative. Quantitative research is a research method that uses the process of data in the form of numbers as a tool to analyze and conduct research studies, especially regarding what has been studied (Kasiram, 2008). According toSugiyono (2003: 11) Associative research is research that aims to determine the influence or relationship between two or more variables.

\section{Population}

Population is the whole object of research (Arikunto, 1998: 115). Definition of population according to Sugiyono (2008: 80) is a region of generalization consisting of objects / subjects that possess the quality and characteristics set by the researcher to be studied and then concluded. The population in this study are construction and building companies listed on the Indonesia Stock Exchange.Total population, which is all twelve company.

Sample

Samples are a portion of the number and characteristics possessed by the population, or a small part of the population members taken according to certain procedures so that they can represent the population. The sample in this study is a Construction and Building Company registered on the Indonesia Stock Exchange which reports consecutive and audited Financial Statements from 2013-2017.Total sampling, which is all 9 company.

\section{Data Type}

The type of data used in this study is secondary data. Secondary data is data that comes from records that exist in the company and from other sources, namely by conducting library studies (Sunyoto, 2016: 21).

\section{Data Source}

The data sources in this study are secondary data obtained from the Indonesia Stock Exchange website (www.idx.co.id), and www.sahamok.com.

\section{Data Collection}

According to Sugiyono (2013: 224) data retrieval techniques are the most strategic step in research, because the main purpose of research is to obtain data. In this study the data collection techniques used the Literature Technique and Documentation Technique.

\section{Data Analysis Technique}

According to (Bogda \& Biklen, 1975) data analysis is a process that formally specifies efforts to find themes and formulate hypotheses (ideas) as suggested and as an effort to provide assistance and themes to hypotheses Data analysis in this study uses multiple linear regression analysis techniques for processing data with the help of Statistical software programs Version 20 of the Package for the Social Sciences (SPSS). The use of regression analysis as a data analysis technique begins with a classic assumption test. The classic assumption test is one of the prerequisite tests for multiple linear regression analysis based on Ordinary Least Square, which is one method to determine the influence of independent variables on the dependent variable. The classic assumption test that will be used in multiple linear regression models in this study is the multicollinearity test, heteroscedasticity test, autocorrelation test, and normality test. In this study the regression model used is multiple linear regression analysis.

$$
Y=\beta 0+\beta 1 \times 1+\beta 2 \times 2+\beta 3 \times 3+e
$$

$\begin{array}{ll}\mathrm{Y} & : \text { Company Financial Perfo } \\ \mathrm{X} 1 & : \text { Managerial Ownership } \\ \mathrm{X} 2 & : \text { Institutional Ownership } \\ \mathrm{X}_{3} & : \text { Dividend Policy } \\ \beta 0 & : \text { Intercept (Constant) } \\ \beta 1, \beta 2, \beta 3 & : \text { Regression Coefficient. } \\ \mathrm{e} & : \text { Error }\end{array}$

Error tolerance $(\alpha)$ is set at $5 \%$ with a significance of $95 \%$.

\section{RESULT ANDDISCUSSION}

\section{Descriptive Statistics}

Descriptive statistics function to provide an overview or description of a research data that can be seen from the average value, standard deviation, maximum value and minimum value. The results of descriptive statistics are shown in the table as follows: 
Table 1:Descriptive Statistics Results

\begin{tabular}{|l|c|c|c|c|c|}
\hline & N & Min & Max & Mean & Std Deviation \\
\hline Managerial Ownership & 9 & 0.000 & 0.120 & 0.022 & 0.038 \\
Institutional Ownership & 9 & 0.090 & 0.850 & 0.432 & 0.219 \\
Dividen Policy & 9 & 0.000 & 3.940 & 0.358 & 0.574 \\
Financial Performance & 9 & -0.250 & 0.150 & 0.045 & 0.056 \\
Valid N (listwise) & 9 & & & & \\
\hline
\end{tabular}

Based on descriptive table statistics above shows that of the 9 construction and building companies over a period of 5 years namely 2013-2017, the average value of managerial ownership is 0.022 with a minimum value of 0.000 and a maximum value of 0.120 and a standard deviation of 0.038 . Based on the descriptive table statistics above shows that of the 9 construction and building companies over a period of 5 years namely 2013-2017, the average value of institutional ownership is 0.432 with a minimum value of 0.090 and a maximum value of 0.850 and a standard deviation of 0.219 .

Based on descriptive table statistics above shows that of the 9 construction and building companies over a period of 5 years namely 2013-2017, the average value of dividend policy is 0.358 with a minimum value of 0.000 and a maximum value of 3.940 and a standard deviation of 0.574 . Based on the descriptive table statistics above shows that of the 9 construction and building companies over a period of 5 years namely 2013-2017, the average value of financial performance is 0.045 with a minimum value of -0.250 and a maximum value of 0.150 and a standard deviation amounting to 0.056 .

\section{Multicollinearity Test}

Multicollinearity test can be done by looking at the value of toolerance and variance inflating factor (VIF). The following is the result of testing multiple linear regression models in this study:

Tabel2: Multicollinearity Test Results

\begin{tabular}{|l|c|c|c|c|c|}
\hline \multirow{2}{*}{ Model } & \multicolumn{2}{|c|}{$\begin{array}{c}\text { Undstandardized } \\
\text { Coefficient }\end{array}$} & $\begin{array}{c}\text { Standardized } \\
\text { Coefficient }\end{array}$ & \multicolumn{2}{c|}{ Collinearity Statistics } \\
\cline { 2 - 6 } & B & Std Error & Beta & Tolerance & VIF \\
\hline Constant & 0.065 & 0.020 & & & \\
Managerial Ownership & 0.799 & 0.233 & 0.820 & 0.876 & 1.142 \\
Institutional Ownership & 0.006 & 0.042 & 0.035 & 0.859 & 1.164 \\
Dividen Policy & -0.113 & 0.042 & -0.691 & 0.781 & 1.280 \\
\hline
\end{tabular}

Based on the Coefficient table above managerial ownership variables tolerance value is 0.876 and VIF value is 1.142. Institutional ownership tolerance value is 0.859 and VIF value is 1.164 and dividend policy tolerance value is 0.781 and VIF value is 1.280 . The three independent variables get tolerance values> 0.10 and VIF values $<10.00$. So, it can be concluded that the regression model in this study did not occur multicollinearity.

\section{Heteroscedasticity Test}

Heteroscedasticity tests can be done using the Glejser test. The principle of heteroscedasticity test using the glejser test is to regress the independent variable to the Absolute Residual value or Abs_RES. The following is the result of testing multiple linear regression models in this study:

Tabel 3:Heteroscedasticity Test Results

\begin{tabular}{|l|c|c|c|c|c|}
\hline \multirow{2}{*}{ Model } & \multicolumn{2}{|c|}{$\begin{array}{c}\text { Undstandardized } \\
\text { Coefficient }\end{array}$} & $\begin{array}{c}\text { Standardized } \\
\text { Coefficient }\end{array}$ & & \\
\cline { 2 - 4 } & B & Std Error & Beta & t & Sig. \\
\hline Constant & 0.023 & 0.013 & & 1.850 & 0.124 \\
Managerial Ownership & -0.067 & 0.145 & -0.196 & -0.461 & 0.664 \\
Institutional Ownership & -0.026 & 0.026 & -0.428 & -0.999 & 0.364 \\
Dividen Policy & 0.007 & 0.026 & 0.119 & 0.265 & 0.801 \\
\hline
\end{tabular}


Based on the table of Coefficient above the value of the significance of the managerial ownership variable is 0.664 . The value of the institutional ownership variable is 0.364 . And the value of the dividend policy significance is 0.801 . The three independent variables in this study obtained a significance value> 0.05 . So, it can be concluded that the regression model in this study did not occur heteroscedasticity.

\section{Autocorrelation Test}

The autocorrelation test in this study was carried out using the durbin watson test or it could be called a DW test. Watson durbin test is used for level one autocorrelation and requires the presence of constants in the regression model and there is no lag variable between the independent variables. The following is the result of testing multiple linear regression models in this study:

\section{Tabel 4: Autocorrelation Test Results}

\begin{tabular}{|l|r|}
\multicolumn{2}{c}{ Runs Test } \\
\hline \multicolumn{1}{|c|}{} & $\begin{array}{c}\text { Undstandardized } \\
\text { Residual }\end{array}$ \\
\hline Test Value $^{\mathrm{a}}$ & -0.00629 \\
Cases < Test Value & 4 \\
Cases >= Test Value & 5 \\
Total Cases & 9 \\
Number of Runs & 4 \\
Z & -0.683 \\
Asymp. Sig. (2 -tailed) & 0.495 \\
\hline
\end{tabular}

Based on the Runs Test table above the Asymp value. Sig. (2-tailed) is 0.495. Thus it can be concluded that the regression model in this study has no autocorrelation based on the value of Asymp. Sig. (2-tailed) which is greater than 0.05 .

\section{Normality Test}

Normality test using SPSS software by reading the kolmogorov-smirnov table. The following is the result of testing multiple linear regression models in this study:

\section{Tabel 5: Normality Test Results}

One Sample Kolmogrov Smirnov Test

\begin{tabular}{|c|c|c|}
\hline & & $\begin{array}{c}\text { Undstandardized } \\
\text { Residual }\end{array}$ \\
\hline $\mathrm{N}$ & & 9 \\
\hline \multirow[t]{2}{*}{ Normal Parameters } & Mean & 0.000 \\
\hline & Std Deviation & 0.019 \\
\hline \multirow[t]{3}{*}{ Most Extreme Different } & Absolute & 0.331 \\
\hline & Positive & 0.331 \\
\hline & Negative & -0.228 \\
\hline Kolmogrov Smirnov Z & & 0.993 \\
\hline Asymp. Sig (2 tailed) & & 0.278 \\
\hline
\end{tabular}

Based on the kolmogorov-smirnov table above the Asymp value. Significance is 0.278 . So based on the basis of decision making in the normality test of this research the distribution of normal data is indicated by the value of Asymp. Significance> 0,05.

\section{Simultaneous Hypothesis Test (F Test)}

The $\mathrm{F}$ test is a test used to determine the influence of simultaneous independent variables on the dependent variable. The following are the results of this research's $F$ test:

\section{Tabel 6: F Test Results}

The Influenee Of Managerial Ownership, Institutional ONOWA Anthith, And Dividend Policy On The Finaneial Performance Of Construction And Building Companies Listed On The Indonesia Stock Exchange 2013-2017

Yeni Sofiana $^{1}$, Agus Sukoco ${ }^{2}$, Joko Suyono ${ }^{3}$ 


\begin{tabular}{|c|c|c|c|c|c|}
\hline Model & $\begin{array}{c}\text { Sum of } \\
\text { Squares }\end{array}$ & df & $\begin{array}{c}\text { Mean } \\
\text { Square }\end{array}$ & $\mathbf{F}$ & Sig. \\
\hline Regression & 0.009 & 3 & 0.003 & 4.986 & $0.058^{\mathrm{a}}$ \\
\hline Residual & 0.003 & 5 & 0.001 & & \\
\hline Total & 0.012 & 8 & & & \\
\hline
\end{tabular}

Based on the ANOVA table above the significance value the results of the F test are 0.058 and the calculated $\mathrm{F}$ value is 4.986 . The table $\mathrm{F}$ value is 4.76 . So, it can be concluded that the hypothesis is accepted, based on the calculated $F$ value which is greater than the value of the $F$ table $(4.986>4.76)$ and the significance of 0.05 according to the standard basic decision-making data.

\section{Partial Hypothesis Test (t Test)}

The $\mathrm{t}$ test is a test used to determine whether the independent variable partially influences the dependent variable. The following are the results of this research $t$ test:

Tabel 7: $\mathbf{t}$ Test Results

Coefficients

\begin{tabular}{|l|c|c|c|c|c|}
\hline \multirow{2}{*}{ Model } & \multicolumn{2}{|c|}{$\begin{array}{c}\text { Undstandardized } \\
\text { Coefficient }\end{array}$} & $\begin{array}{c}\text { Standardized } \\
\text { Coefficient }\end{array}$ & & \\
\cline { 2 - 4 } & B & Std Error & Beta & T & Sig. \\
\hline Constant & 0.065 & 0.020 & & 3.240 & 0.023 \\
Managerial Ownership & 0.799 & 0.233 & 0.820 & 3.428 & 0.019 \\
Institutional Ownership & 0.006 & 0.042 & 0.035 & 0.146 & 0.890 \\
Dividen Policy & -0.113 & 0.042 & -0.691 & -2.727 & 0.041 \\
\hline
\end{tabular}

Based on the coefficient table above the value of the significance of the managerial ownership variable is 0.019 and the calculated $\mathrm{t}$ value is 3.428. The significance value of institutional ownership variable is 0.890 and the value of $t$ count is 0.146 . And the value of the dividend policy significance is 0.041 and the calculated $\mathrm{t}$ value is -2.727 . The value of $\mathrm{t}$ table can be searched using the following formula $\mathrm{t}$ table $=$ $(\alpha / 2$; df residual) obtained by numbers $(0.025 ; 5)$ In the distribution table $t$ it is known that the value of $t$ table is 2.571 . So it can be concluded that managerial ownership hypothesis is accepted with a significance value of $0.019<0.05$ and the calculated $t$ value is 3.428> 2.571. Institutional ownership hypothesis is rejected with a significance value of $0.890>0.05$ and the value of $t$ count is $0.146<2.571$. Dividend policy hypothesis is accepted with a significance value is $0.041<0.05$ and the value of $t$ count is $-2.727>2,571$.

\section{Determination Coefficient Test $\left(\mathbf{R}^{2}\right)$}

The coefficient of determination test is used to determine how much influence the independent variable has on the dependent variable. The main requirements so that the test of the coefficient of determination can be used is the result of the $\mathrm{F}$ test indicating the simultaneous influence of independent variables on the dependent variable or can also be called the accepted hypothesis. The following are the test results of the coefficient of determination:

Tabel 8: Determination Coefficient Test Results

\begin{tabular}{|c|c|c|c|c|}
\hline Model & Rodel Summary \\
\hline 1 & $0.866^{\mathrm{a}}$ & 0.749 & 0.599 & $\begin{array}{c}\text { Std error of the } \\
\text { Estimate }\end{array}$ \\
\hline
\end{tabular}

Based on the above table it is known the value of R Square or the coefficient of determination is 0.749. It can be concluded that the independent variables simultaneously in this study affect the dependent variable by $74.9 \%$.

\section{Multiple Linear Regression Analysis}

The Influence Of Managerial Ownership, Institutional Ownership, And Dividend Policy On The Financial Performance Of Construction And Building Companies Listed On The Indonesia Stock Exchange 2013-2017

Yeni Sofiana $^{1}$, Agus Sukoco ${ }^{2}$, Joko Suyono ${ }^{3}$ 
Multiple linear regression analysis is used to determine whether there are influences of two or more independent variables on the dependent variable. This study uses three independent variables and one dependent variable. The following is a summary of the results of multiple linear regression analysis based on the tests conducted in this study:

Tabel9: Summary of Results of Multiple Linear Regression Analysis

\begin{tabular}{|c|c|c|c|}
\hline \multicolumn{4}{|c|}{ Summary of Results of Multiple Linear Regression Analysis } \\
\hline Variable & Regression Coefficient & t count & Sig \\
\hline Constant & 0.065 & & \\
\hline Managerial Ownership & 0.799 & 3.428 & 0.019 \\
\hline Institutional Ownership & 0.006 & 0.146 & 0.890 \\
\hline Dividen Policy & -0.113 & -2.727 & 0.041 \\
\hline F count & 4.986 & & \\
\hline R Square & 0.749 & & \\
\hline
\end{tabular}

Based on the table above it can be concluded that the multiple linear regression equation in this study is as follows:

$$
Y=0.065+0.799+0.006-0.113
$$

Regression coefficients that show positive results indicate that the independent variables change in the direction of the dependent variable. While the regression coefficient which has a negative result indicates that the independent variable is not in the direction of the dependent variable.In the regression equation obtained from the above calculation shows managerial ownership variables and institutional ownership have a positive regression coefficient which implies that managerial ownership and institutional ownership have a direct influece on the company's financial performance. While the dividend policy variable regression coefficient is negative which implies that dividend policy moves in the opposite direction to the company's financial performance in this study.

The following is the discussion of the results of multiple linear regression analysis of each independent variable on the dependent variable:

\section{Managerial Ownership and Financial Performance}

Based on the result of the analysis carried out using the help of SPSS software, it can be concluded that managerial ownership has a positive and significant influence on the company's financial performance. This can be seen from the significance level of 0.019 which is less than the standard significance of 0.05 and the value of $t$ count is 3.428 , which is greater than $t$ table 2.571. The result of this study is supported by previous research conducted by Candradewi, Bagus, \& Sedana (2016) which states that managerial ownership has a significant influence on Return On Assets (ROA) where ROA is an indicator in financial performance variables.

With managerial ownership where shares are owned by management, the company's financial performance will increase because management will be motivated to improve its performance in managing the company and will act carefully in every decision making because they will share the consequences of the decisions taken. Increasing financial performance will also increase the benefits obtained when dividend distribution for shareholders.

\section{Institusional Ownership and Financial Performance}

Based on the result of the analysis carried out using the help of SPSS software, it can be concluded that institutional ownership has a positive but not significant influence on the company's financial performance. This can be seen from the significance level of 0.890 which is more than the standard of significance of 0.05 and the value of $t$ count of 0.146 , whose value is smaller than $t$ table 2.571 . The result of this study is supported by previous research conducted by Wiranata \& Nugrahanti (2013) which states that institutional ownership does not influence the company's profitability, where Return On Assets (ROA) which are indicators in financial performance variables in this study include profitability ratios. The research of 
Murni (2015) also states that institutional ownership does not have a significant influence on financial performance.

In this study institutional ownership did not have a significant influence on financial performance, contrary to the Hykaj (2016) study which states that the presence of institutional shareholders has a positive impact on financial performance. This shows that institutional ownership in this study is still not maximal in carrying out its control functions. So that it has not been able to control the company's management to act in accordance with the company's goals, which is to increase profits to the maximum that will certainly also improve the company's financial performance.

\section{Dividend Policy and Financial Performance}

Based on the result of the analysis carried out using the help of SPSS software it can be concluded that dividend policy has a negative and significant influence on the company's financial performance. This can be known from the significance level of 0.041 which is less than the standard significance of 0.05 and the value of $t$ count is -2.727 , which is greater than $t$ table 2.571 . The result of this study is supported by previous research conducted by Dogan \& Topal (2014) which states that dividend policy has an influence on the company's financial performance.

The dividend policy of a company will be determined at the General Meeting of Shareholders (GMS) conducted at a certain period agreed upon by the shareholders. Dividend policy in this study has a negative and significant influence. These results indicate that dividend policy decisions have the opposite influence to the company's financial performance. If the dividend distribution decision is shared with high shareholders, the return on assets of a company will decrease and vice versa. Therefore, during the general meeting shareholders must take and determine decisions that are beneficial for both parties, both the shareholders and the operational interests of the company because every decision taken will greatly affect each other.

\section{Managerial Ownership, Institutional Ownership, Dividend Policy and Financial Performance}

Based on the result of the analysis carried out using the help of SPSS software, it can be concluded that managerial ownership, institutional ownership and dividend policy simultaneously have a significant and positive influence on the company's financial performance. This can be seen from the significance level of 0.05 which is equal to the standard significance of 0.05 and the calculated $f$ value of 4.986 which is greater than $\mathrm{f}$ table 4.760 . So the hypothesis formulation $\mathrm{H} 4$ in this study was accepted.

These result indicate that if managerial shareholders and institutional shareholders carry out their control functions well and professionally, the company's goals will be achieved. Likewise, every decision taken during a general meeting of shareholders must be decided on dividend policies that benefit all parties and companies, so that the company will grow and get the maximum benefit and the company's financial performance will also increase as well.

\section{CONCLUSION}

Based on the problems formulated, the initial hypothesis made, the research method test and the results of the analysis of the tests conducted in the previous chapter, the results of this study can be summarized as follows:

1. Partially managerial ownership has a positive and significant influence on financial performance of construction and building companies listed on the Indonesia Stock Exchange in 2013-2017.

2. Partially institutional ownership has a positive but not significant influence on financial performance of construction and building companies listed on the Indonesia Stock Exchange in 2013-2017.

3. Partially dividend policy has a negative and significant influence on financial performance of construction and building companies listed on the Indonesia Stock Exchange in 2013-2017.

4. Simultaneously managerial ownership, institutional ownership and dividend policy have a positive and significant influence on financial performance of construction and building companies listed on the Indonesia Stock Exchange in 2013-2017.

\section{REFERENCE}

Arikunto, S. (1998). Prosedur Penelitian Suatu Pendekatan Praktek. In Metode Penelitian (p. 115). Jakarta: Rineka Cipta.

Boediono, G. S. (2005). Kualitas Laba: Studi Pengaruh Mekanisme Corporate Governance dan Dampak Manajemen Laba Dengan Menggunakan Analisis Lajur. Simposium Nasional Akuntansi.

The Influence Of Managerial Ownership, Institutional Ownership, And Dividend Policy On The Financial Performance Of Construction And Building Companies Listed On The Indonesia Stock Exchange 2013-2017

Yeni Sofiana $^{1}$, Agus Sukoco ${ }^{2}$, Joko Suyono ${ }^{3}$ 
Bogda, R. C., \& Biklen, S. knopp. (1975). Metodologi Penelitian Kualitatif. In Metodologi Penelitian Kualitatif. bandung: Remadja.

Candradewi, I., Bagus, I., \& Sedana, P. (2016). Pengaruh Kepemilikan Manajerial , Kepemilikan Institusional Dan Dewan Komisaris Independen Terhadap Return On Asset Menghadapi Persaingan Bisnis Yang Kompetitif. E-Jurnal Manajemen Unud, 5(5), 3163-3190.

Dogan, M., \& Topal, Y. (2014). The Influence of Dividend Payments on Company Performance: The Case of Istanbul Stock Exchange (BIST). In European Journal of Business and Management.

Fahmi, I. (2012). Analisis Laporan Keuangan. In Analisis Laporan Keuangan (2nd ed., p. 2). bandung: Alfabeta.

Houston, \& Brigham. (2009). Manajemen Keuangan. In Manajemen Keuangan (12th ed.). Jakarta: Erlangga.

Husnan, S., \& Pujiastuti, E. (1998). Dasar Dasar Manajemen Keuangan. In Dasar Dasar Manajemen Keuangan (2nd ed., p. 381). Yogyakarta.

Hykaj, K. (2016). Corporate Governance, Institutional Ownership, and Their Effects on Financial Performance. European Scientific Journal, ESJ. https://doi.org/10.19044/esj.2016.v12n25p46

Jensen, M. C. ., \& Meckling, W. H. (1976). Theory Of The Firm: Managerial Behavior, Agency Costs and Ownership Structrure.Financial of Economics, 3, 305-360.

Kasiram, M. (2008). Metode Penelitian Kuantitatif-Kualitatif. In Metode Penelitian Kuantitatif-Kualitatif. Malang: UIN Malang Press.

Kasmir. (2016). Analisis Laporan Keuangan. In Analisis Laporan Keuangan (p. 196). Jakarta: Raja Grafindo Persada.

Melinda, F. I., \& Sutejo, B. S. (2019). Interdependensi Kepemilikan Manajerial dan Kepemilikan Institusional Serta Pengaruhnya Terhadap Kinerja Keuangan.Journal of Management and Business. https://doi.org/10.24123/jmb.v7i2.127

Murni, Y. (2015). The Influence of Managerial Ownership, Institutional Ownership and Voluntary Disclosure on Financial Performance and its Implication on The Corporate Value. International Journal of Business and Management Investion, 4(5), 52-64.

Sartono, A. (2001). Manajemen Keuangan Teori dan Aplikasi (keempat). Yogyakarta: BPEF.

Sugiyono. (2003). Metode Penelitian Bisnis. In Metode Penelitian (1st ed., p. 11). bandung: Alfabeta.

Sugiyono. (2008). Metode Penelitian Kunatitatif Kualitatif dan R\&D. bandung: Alfabeta.

Sugiyono. (2013). Metode Penelitian Kuantitatif, Kualitatif dan R\&D. In Metode Penelitian (p. 224). bandung: Alfabeta.

Sujoko, \& Subiantoro, U. (2007). Pengaruh struktur kepemilikan saham leverage faktor intern dan faktor ekstern terhadap nilai perusahaan (studi empirik pada perusahaan manufaktur dan non manufaktur di bursa efek jakarta). Jurnal Manajemen Dan Kewirausahaan.

Sunyoto, D. (2016). Metodologi Penelitian Akuntansi. bandung: PT Refika Aditama.

Weston, J. F., \& Copeland, T. E. (1992). Manajemen Keuangan. In Manajemen Keuangan (9th ed., p. 125). Jakarta: Binarupa Aksara.

Weston, J. F., \& Copeland, T. E. (1996). Manajemen Keuangan (Kesembilan). Jakarta: Erlangga.

Wiranata, Y. A., \& Nugrahanti, Y. W. (2013). Pengaruh Struktur Kepemilikan Terhadap Profitabilitas Perusahaan Manufaktur di Indonesia. Jurnal Akuntansi Dan Keuangan, 15(1), 15-26. https://doi.org/10.9744/jak.15.1.15-26

Yadnyana, I. K., \& Wati, N. W. A. E. (2011). Struktur Kepemilikan, Kebijakan Dividen dan Nilai Perusahaan Perusahaan Manufaktur Yang Go Public. Jurnal Keuangan Dan Perbankan, 15(1), 58-65. 